\title{
Pursuing Opportunities Available to Support Your Own Learning: A Case Study: University of Guyana Library
}

\author{
Debra Lowe \\ University of Guyana Library, Turkeyen Campus, University of Guyana \\ Turkeyen, P.O. Box 101110, Georgetown, Guyana, South America
}

Tel: 592-222-5401Ｅ-mail: debra.lowe@uog.edu.gy

\begin{abstract}
Simmone La Rose
University of Guyana Library, Berbice Campus, University of Guyana

Tain, Corentyne, Berbice, P.O. Box 101110, Guyana, South America

Tel: 592-337-2300Ｅ-mail: andrea1st2002@yahoo.com

Nalisa Bhagwandin

University of Guyana Library, Berbice Campus, University of Guyana

Tain, Corentyne, Berbice, P.O. Box 101110, Guyana, South America

Tel: 592-337-2300Ｅ-mail: nalisa.bhagwandin@uog.edu.gy
\end{abstract}

Received: June 13, 2019 Accepted: October 11, 2019 Published: November 6, 2019

doi:10.5296/ijld.v9i4.15768 URL: https://doi.org/10.5296/ijld.v9i4.15768

\begin{abstract}
This article provides an assessment of the pathways Librarians at the University of Guyana Library (UGL) explored to achieve continual learning for professional growth and self-development.

The writers adopted a survey method to capture data from sixteen senior professionals from the University of Guyana Library. The findings revealed that while the University of Guyana Administration provided some avenues for professional growth and development for all professionals, there were some areas that required a more structured and equitable approach. The findings indicated that much more can be done to facilitate growth and development for
\end{abstract}


senior Library professionals, particularly in the field of Librarianship. From the discussions, the researchers concluded that in spite of the limited access to available resources, Library senior professionals actively pursued alternative avenues to enhance and advance learning. This was intended to acquire current knowledge and practice so that they may provide a higher quality of service to their clientele; further, their experience (in the process) will assist in enhancing their professional development and personal growth.

Keywords: Guyana University, Turkeyen - Tain Campus Libraries, Professional Development, Personal development, Continuing Education Programmes (CEP), Library Professional and Information Communication Technology (ICT)

\section{Introduction}

One of the major agents of change influencing the work of professional librarians is the rapid expansion and variation in the information and knowledge environment which has serious implications for the delivery of efficient service to library patrons. As the information explosion is taking place in the wider society, efforts must be made to ensure that there is a provision of opportunities for workplace learning. Professionals need to experience continual professional growth and self-development so that they may make valuable contributions to their organisation and clients. Continuous Learning (CL) becomes pivotal to the enhancement of the professional library community if the library is to remain relevant in the burgeoning field of advanced communication technology.

The literature discusses professional development in terms of the human resource factor. To this end, Gilley and Eggland (as cited in Gilley \& Maycunich, 2000) defined Human Resource Development as structured educational activities within the organisation with the intent to enhance staff performance and/or individual development. They further noted that building the capacity of human resource serves to improve the job, the individual as well as the organisation.

An evaluation of present knowledge and skill and the possibility of reaching higher levels of understanding and advanced library processes are factors that may stimulate librarians to become engaged in professional development. For Librarians, the plan is to engage in continual development while simultaneously applying knowledge acquired almost immediately in the work environment. The probability of the immediate transfer of knowledge acquired will tend to be high, leading to satisfaction and the perception of intrinsic rewards. Although the overall design portrayed a pathway to the development of professional library skills as the prime focus, flexibility in the plan and its implementation allows individual personnel to identify their niche areas.

From an organisational standpoint, an integral part of planning necessitates simultaneously addressing its needs, challenges, creating an economic value for itself while ensuring workers satisfaction and advancement. The organisation therefore must establish operational policies and practices that are beneficial to them and simultaneously benefit the social and economic wellbeing of the employees (Porter \& Kramer 2011).

Academic libraries that adopt the concept of addressing societal needs will be better able to 
establish and provide more innovative services to their users. To better achieve these goals necessitates the acquisition of new skills and proficiencies and the updating of old ones by the library professionals.

However, Knight (2015) noted that the organisation, must ensure that the Human Resource Development (HRD) plays an integral role in the main business processes if it is to accomplish a competitive business strategy. Making Human Resource Development an important aspect of the Library's processes will benefit both the Library and the Library professionals. Recognising this positive impact, Library professionals in academic libraries have already commenced work using varying approaches to plan so as to ensure that the role of the Human Resource Division forms an integral part of their operational processes.

This research paper delineates the pathways library professionals at the University of Guyana (UG) explored to achieve continual learning, professional growth, and self-development.

\section{Background}

The University of Guyana Library comprises one main library referred to as the Turkeyen Campus Library, Georgetown, with one sister Campus Library referred to as the Tain Campus Library, in Berbice located approximately 120 kilometers away.

\subsection{Staffing at the University of Guyana Library}

The current composition of staff at the Turkeyen and Tain campus libraries are outlined below:

- Turkeyen Campus - 15 senior professionals and approximately 80 junior professionals;

- Tain Campus - 3 senior professionals and 5 junior professionals

A senior library professional is someone who has been recruited with a Degree and a junior professional is someone who has been recruited with a minimum of passes in five or more subjects at Caribbean Examination Council (CXC)/General Certificate of Education (GCE) O' level subjects. The subjects which must include mathematics and English language must be between the levels of grades one to four (I-IV).

For this research, the concept, professionally trained is referred to a professional who has acquired a Certificate or a Bachelor or Master of Library and Information Science degree. Alternatively, in the UG system, a professional is one who is academically qualified with a Bachelor's degree, Post Graduate Diploma and a Master degree in other subject disciplines and is assigned to a professional post. These persons also may be assigned to a professional library post.

Generally, in Guyana, there has always been a paucity of librarians who have been educated professionally in Library and Information Science. However, while some libraries sought to provide avenues for professional development for their members, the University of Guyana Library (UG Library) still lags. Given the many constraints facing the University of Guyana, the recruitment of professionally educated librarians is oftentimes a challenge. In addition, the University of Guyana may find it difficult to attract professional librarians because of its less than competitive benefits package. The University of Guyana Library has only three senior 
library professionals who were trained and holds a Master in Library and Information Science (LIS). The basic criteria for recruitment at the level of a junior library professional are five subjects inclusive of Mathematics and English passes in Grade I to IV at Caribbean Examination Council (CXC) or a Certificate in Technical Studies from a recognised institution.

It appears as though the Library and Information Science profession has not been considered as a critical area of focus by successive governments of Guyana and to some extent, the successive University Administrations. Therefore, scholarships for further professional development in this area, for example, have not occurred.

\section{Literature Review}

\subsection{Professional Development and Continual Learning}

In discussing Human Resource Development (HRD) which takes in professional development, it is difficult to ignore the personal development path that is also associated with this process. James, Phillip, Herbert, Augustin, Yamin-Ali, Ali, and Rampersad (2013) noted that continuous learning influences participants' pedagogy, their personal and interpersonal growth as well as their professional development (PD). Therefore, like every profession, involvement in continuous education/professional development is critical for the growth of professional in the Academic Library. Professional development for academic librarians satisfies the requirement for continued pursuit of knowledge and competencies which are not realised through formal education or hands-on training.

Mizell (2010) pointed out that in most instances, the term, PD, usually refers to participation in an official library-related activity, for example, conferences/seminars/workshops, collective learning among co-workers, acquisition of a University qualification. Further, as hinted earlier PD for academic librarians addresses the need for continuous acquisition of knowledge and competencies that may not be realised through informal settings or hands-on training such as discussions, independent reading and research.

According to the National Institute of Health (2015), efforts by Library professionals to regularly upgrade their skills, abilities and knowledge is classified as continuous learning. Further, continuous learning takes place from experiences gained through the years of working within the library profession since it allows not only for hands-on learning but also re-examining assumptions, values, methods, policies, and practices.

Academic Libraries would need a paradigmatic shift of accessing investment avenues that would attract Librarians with a Master in Library and Information Science while simultaneously providing continuous training and development for existing staff in order to retain core knowledge professionals (Knight, 2013 as cited in Knight, 2015). This is particularly important given that, fundamentally, it is the employee engagement, the training and development of the work force that Human Resource Development places emphasis on.

In this information age, knowledge workers are classified as a key source of intellectual capital. Therefore, the university as a knowledge-based institution will be required to make meaningful investments to ensure that the library's intellectual capital continues to generate new 


\section{Macrothink}

knowledge as a significant distinction (Bratton \& Gold, 2007). This therefore means that Human Resource Development will assume greater significance. This has led Drucker (1992) to conclude that the critical role of knowledge workers to the institution must be viewed as both the means to production within a company as well as being critical to the work as a product. This therefore suggests that Librarians who are core knowledge workers will possess the critical specific skills required by the library to serve the University's students and faculty. In addition, library professionals with library specific skills are the ones with the scope which allows them to attain competitive advantages over their co-workers who are unskilled. In addition, by virtue of their library skills training, Library professionals will outperform their counterparts due to their acquisition of those distinctive skills and competencies.

As Gilley and Maycunich (2000) put it, Human Resource Development should be viewed as the essential contributor to the Library's purpose. In addition, they underscored the need for the Library professionals to ensure that the interest of the Library is treated with priority and that they must contribute to the shaping of the Library's strategic organisational goals.

\subsection{Social, Personal and Professional Abilities}

Kar (2012) posits that striving only for education or academic excellence is not enough for professional development. Instead, individuals will need additional expertise such as the ability to engage in self-evaluation which is learning from past experiences to better improve in future approaches to work. This will allow for continued sustainability and equilibrium in their professional and personal life.

Similarly, Larsen (2007), also noted that personal skills may include the ability to communicate, to learn, commit, prepare for changes, effect personal planning, personal management, stress management, and pedagogical skills. Further, Larsen (2007) stated that libraries as organisations will function within specific work duties based on the availability of resources of the social and academic environment. This therefore means that Libraries will be involved in scenario planning, cooperation issues, conflict handling, team building, collaborating just to name a few.

In addition to the traditional core skills such as cataloguing, classification, information retrieval, reference work, and user education, Library professionals will also be required to acquire skills in marketing, branding and communication. The new and emerging skills are necessary due to the electronic context, and all have a place in facilitating the effective use of this changing information environment.

Therefore, it is evident that pursuing opportunities available other than the formal Library studies becomes necessary. And this is so because the informal opportunities are also crucial in shaping the library professional for their role in the delivery of services to the users as well as support the library functions. As Gremmels (2013) posited, with the evolving roles of library professionals there is a need for the acquisition of new skills and competencies. University Administrators must seek to address Professional development for library professionals alongside Faculty or face the consequences of being unable to retain quality library professionals. 


\subsection{The Advantages and Disadvantages of Professional Development}

Pan and Hovde (2010) posited that Professional development for academic librarians serves to guarantee that there is continuity of acquired knowledge and training to enhance the skills set that are not achieved through the formal education or hands-on training on the job. The continuity of the acquisition of knowledge and skills set becomes necessary given the rapidity of changes that take place as a result of the information technology. The need for the continued training is particularly necessary given the rapidity with which the information technology changes. Information technology has become a vital tool to the characteristics of contemporary academic libraries and operates as the element that librarians use to share information with other professionals.

Block (as cited in Pan \& Hovde, 2010) posited that the benefits of professional development are twofold; with benefits for the individual and the organization. The benefits of PD for the individual is derived through continuous acquisition of new knowledge and competencies which serves as a catalyst to enhance on the job performance through application of new knowledge. In addition, improved performance through the acquisition and application of new knowledge and skill can be linked to advancements such as promotion either through certification and or staff assessment. From a psychological level, the perception is that enhanced knowledge and improved skills set can result in job satisfaction resulting in less stress on the job, which can result in the improvement of library services which benefits the Library.

Davis (2011) asserted that from an employee's point of view PD is about further learning to lengthen and enhance their career. For the employer, PD is about ensuring that employees have the knowledge and enthusiasm to do their job in the best possible way. Further, continuous training of the employees results in enhanced effectiveness and efficiency on the job Davis (2011). Moreover, training old staff to improve their skills is quicker and more cost-effective than adding new staff to the workforce. In addition, being singled out for training tends to suggest feelings of being special, receiving recognition and reward for hard work and can also have a positive spin-off effect by inspiring other employees. Davis (2011) also noted that staff must be able to cope with changing roles which is possible only through continued learning contact with other professionals and exposure to new ideas.

On the contrary, Davis (2011) had another view, arguing that there was fear that if employers improved their staff competencies, the staff may seek better employment elsewhere. However, Corwin (2011) is of the view that in terms of professional development, employees do not only sign up for workshops, to attend conferences and complete skill certificate to be promoted, but they also do so to prepare for the next job; the job that does not exist.

The American Library Association (2013) recognising the challenge to recruit library professionals with a Library degree, stated on its website that it was a general challenge for libraries to recruit Library professionals with a Library Science degree, even at the level of a Director due to the paucity of trained professionals in the field. To this end, libraries are forced to recruit staff with degrees in regular subject discipline or persons who may have library experience. 
Munde (2000) in her support of the hiring trends due to the paucity of professionally trained Librarians, noted that academic librarians are now engaged in different tasks and services, given the need to reinvent library work to suit the competencies of library professionals. Given the trends in the hiring practices, the importance of seeking professional development becomes an integral part of the workplace practice.

\subsection{Who is Responsible for Professional and Personal Development?}

\subsubsection{The Individual?}

Havener and Stolt (1994) suggest that typically it is the responsibility of the employee to locate PD opportunities. Information can often be found through the Human Resources office or a similar department within an organisation. The perception is that once the requests are made supervisors must be aware of the professional development opportunities that exist and provide guidance to the employees who are seeking to advance their own skill sets.

Similarly, it is the responsibility of the academic librarians to seek ways to invest in self-development which will help them to become more equipped with the knowledge and skill set needed to realise their managerial roles.

According to Gilley and Maycunich (2000), HRD has changed from designing and implementing training sessions that are geared towards employee upgrade and ultimately the enhancement of the organisation. Rather, it is the dedicated, determined professional Librarians who assist the organisation by devising ways to create an on-the-job learning environment. Librarians are now designing tools deemed as necessary for library professionals that will enhance their performance at the managerial levels and implement change initiatives.

\subsubsection{The Employer?}

Knight (2015) argued that regardless of the challenges, supervisors must be able to meet the needs of the individual staff to cater for enhancement in skill sets. Hare (1989) cited the provision of release time, leave of absence and institutional financial support as important factors which are classified as aiding in pursuit in PD. He further argued that there is a tendency for the administrators of Academic Libraries to place a strong correlation between the professional development and the funding to provide for same. This therefore seems to suggest that funding for PD is not often listed as a priority when compared to other financial matters of the library.

On the other hand, Havener and Stolt (1994) refuted Hare's (1989) claims about the correlation between the professional development and funding and posited that there was no correlation between the financial support from the institution, time off to pursue the professional development activities and the acquisition of PD. What Havener and Stolt (1994) study shows is that a significant amount of Library professionals sought to participate in one or more workshops without any financial support from the Institution. The latter theory put forward by Havner and Stolt (1994) can be applicable to the acquisition of PD by Library Professionals at the University of Guyana Library in that often times they funded their own development.

In support of Havener and Stolt's (1994) claims of no correlation between the acquisition of PD 
and access to finance from the institution, Kenney and McMillan (as cited in Havener \& Stolt, 1994) also stated that librarians' quests to acquire professional development and growth are based mostly on self-motivation and personal satisfaction which they accomplished with or without institutional support. And this is evident at the University of Guyana Library,

Upward mobility and demand for academic excellence can also be seen as push factors for PD. According to Sapon-White (as cited in Pan \& Hovde, 2010), academic librarians are required to undergo a process of evaluation of their performance in scholarship as well as in librarianship. In addition, in order to be promoted, receive tenure and awarded a yearly increment; academic librarians are mandated by the University to be actively engaged in successful research activities and publications. The situation for academic librarians at UG Library is no different from those at other academic environments. The writers note that there seems to be the perception that there exists an unofficial consensus that many academic librarians are not equipped with the requisite expertise, skills and competencies to conduct research and publish. Sapon-White (as cited in Pan \& Hovde, 2010).

Professional development allows staff, including librarians, to develop skills as well as internal and external relationships to strengthen their own career paths. Many administrators view PD as critical for the expansion of growth in the work performance of the library professional since this will ultimately be beneficial for the workplace. For example, Emory University (2015) views PD as a broad-based concept which is applicable to activities and opportunities that promotes growth through on the job performance and the acquisition of job satisfaction and status. It is their belief that it is important for an individual to achieve personal and professional growth and fulfilment. They have extended the conceptualisation of PD to include on the job enhancement by way of performing additional duties, being engaged in new projects, reassignment and or upward mobility by way of promotion to other sections in the Library.

\subsubsection{A Combined Responsibility?}

Another school of thought by Walton (as cited in Knight, 2015) suggested an alternative approach to professional development and personal growth. They posited that professional development and personal growth can be acquired through a collaborative venture between the Administrators and the employees with the employee being integrally involved at all levels of deliberations on the path they will be required to take.

It is through the collaborative approach that the employees will be able to identify specific learning needs and training opportunities that best suit their areas of interest while simultaneously satisfying the needs of the organisation.

Pursuit in self-development can therefore be seen as beneficial to both the library professionals and the University since it aids library managers in their ability to think strategically for shortand long-term goals of the Library. Engaging in self-development also allows for library professionals to effectively meet, support and shape the goals of the organisation which is necessary for planning for future development and success of the Library.

With the influx of continued changes brought on by globalisation and the continuous technological advancements, academic librarians will be required to sustain their future 


\section{Macrothink

employment rather than expect the organisation to be responsible to do so. In other words, although academic librarians are employed by the University, they must operate as self-employed workers by assuming responsibilities for individual career development. Simultaneously, the role of the Library Administrators would be to encourage Library professionals to undertake additional responsibility which would serve as a catalyst for their own growth and development.

The combined responsibility as proposed by Walton (as cited in Knight, 2015) seems to suggest that given the benefits of professional development to both the organisation and the employees, the task becomes twofold. On one hand, for the individual, continuous acquisition of new information and skills lead to job competencies resulting in performance upgrade and upward mobility; while on the other hand, the organisation benefits from a highly skilled labour force.

\section{The Situation at the University of Guyana Library}

In order to better understand the dynamics of pursuit of PD at the University of Guyana, it is important to identify the various categories of staffing. This is particularly necessary since the opportunities vary according to categories.

\subsection{Categories of Staff at the University of Guyana}

The staff at the University of Guyana is divided into several categories, as follows;

- Senior Academic which constitutes Officers of the University;

- UA Academic which comprises Lecturers and Library Senior Professionals;

- UA Non-academic which comprises staff with a degree that falls under the realm of Administrative Officers and Assistant Personnel Officers;

- UB staff which classifies the junior staff members

The research mainly focuses on the opportunities available to the Academic staff, the category within which the senior staff of the library are placed.

\subsection{Training Policy for Academic Staff}

Part of the University of Guyana's commitment to its academic staff is to provide them with appropriate training, developmental and educational opportunities which should enable them to acquire skills and competencies needed for the benefit of both the institution and the staff's development (University of Guyana Personnel Division, 2011). The University of Guyana endeavours to undertake the following:

- $\quad$ identify staff training and development needs;

- $\quad$ set annual priorities in the light of the developmental needs;

- develop cost training plans to ensure that the priorities are realised;

- provide high-quality induction, training and development programmes; 
- ensure that staff are aware of the available opportunities (University of Guyana Personnel Division, 2011).

While the University of Guyana provides mandatory avenues for staff development, it also encourages staff to pursue personal growth and development. However, both the mandatory avenues and the pursuit of personal growth have their disadvantages, particularly for librarians.

Listed below are some developmental opportunities that are accessible to academic staff members, including the senior Library professionals:

- Induction training for all new staff members;

- Earned Study Leave - 3 months leave with pay which is automatic after the first 3 years of employment to pursue planned academic programme (either research work and/or attachment);

- Sabbatical Leave - 1-year leave with pay which is automatic after 6 years of employment to pursue planned academic programme (either research work and/or attachment). Staff can also pursue higher qualifications during this period;

- Staff Development leave - This extends to a period of 2 - 3 years to pursue graduate studies and is available to newly employed staff as well as staff members with longer service;

- Fellowships (Post-Doctoral);

- Attachments at other universities;

- Tuition Waiver for one programme offered at the University;

- Material Allowance which comprises of US\$300.00 annually to assist in the purchasing of educational material (books or computer related items);

- Support for attending conferences such as - Association of Caribbean University, Research, Institutional Libraries (ACURIL), International Federation of Library Association (IFLA);

- Scholarships for local and overseas studies;

\subsection{Challenges Experienced by Library Senior Staff to Access Opportunities by UG}

According to the University of Guyana Handbook, the opportunities cited above are available to all Academic staff. However, senior library professionals experience some limitations in participating in some of the privileges as set out below:

\subsubsection{Tuition Waivers and Graduate Studies}

While access to tuition waiver is available to all senior staff members, there are some preferences offered to junior lecturers as opposed to senior library professionals. It is mandatory for Assistant Lecturers, who share parallel position to Assistant Librarians, to pursue Graduate studies in Education immediately after recruitment. However, Assistant Librarians are required to wait a period of four years to be eligible to pursue similar studies in the same programme. The rationale for the preference to lecturers is based on the need to lift 
the quality of the teaching faculty. In addition, senior library professionals are also engaged in the teaching/learning process in the areas of lecturing in citations and Information Literacy at all levels of programmes offered at the University given the limited opportunities available to staff generally, this policy should be equitably applied across the board.

There is no scope for pursuing studies in the field of Library and Information Science at the University of Guyana since these programmes are not offered at the university. Providing programmes in Library and Information Science would be beneficial to librarians working at the UG Library, and libraries in Guyana given that there is a dearth of professionally trained librarians in Guyana. Library professionals are left with the only alternative to pursue Graduate studies in other subject disciplines. Further, attempts to gain access to some of these programmes are also met with some challenges due to restrictions placed on them with priority places for teaching staff. For example, librarians desirous of pursuing Graduate studies in Education to enhance their teaching capacity are restricted because priority placements are extended to lecturers and graduate teachers.

\subsubsection{Scholarships}

Another example where librarians face barriers to enjoying available opportunities lies with limited access to scholarships. Traditionally, access to scholarships has been difficult in Guyana. However, this pattern has changed tremendously in recent times with an influx of scholarship offers, but yet the opportunity for librarians is limited. Scholarships are competitive and cater to the needs of studies especially in the Social, Natural and Medical Sciences, Technology and Education, therefore librarians take the opportunity to compete with lecturers across the campus for the available scholarships in the regular subject areas. To further compound the problem quite often, government, donor and university scholarships come with clauses that tend to exclude librarians. Similarly, sponsorship opportunities for librarians to attend professional conferences, workshops and seminars are limited. Ultimately, at the University of Guyana Library, opportunities for advancing knowledge in the field of librarianship are sparse and sporadic.

\section{Steps Taken by UG Librarians to achieve Professional and Personal Development}

To circumvent some of the challenges, librarians have sought alternative means to enhance and advance learning to be informed of current knowledge and practices to be better stewards in the provision of services to their clientele. Library professionals have been determined to enhance self-interest and develop the ability to reflect on managing their own process of transformation in order to find their way to success. In addition, they have acquired the need for self-awareness of their values, beliefs, attitudes, openness as well as their knowledge of their strengths and weaknesses to function in today's world. Library professionals at UG library taking the lead in acquiring self-awareness exemplifies with what Andrén (2012) stated, that the concepts of self-awareness and self-knowledge deepen the understanding of what to learn in the context of self-development.

\section{Methodology}

The aim of this study, sought to provide an assessment of the pathways Librarians at the 
University of Guyana (UG) explored to achieve continual learning for professional growth and self-development, was realised through qualitative and quantitative data collection methods. The survey instruments used for data collection were:

- Convenience sampling, structured one-on-one interviews were conducted with 14 of the Senior professionals from UG Library using a structured interview schedule;

- Self-administered questionnaires which were emailed to the 2 senior library professionals from UG Library who were overseas on study leave and the 3 professionals who worked at the Tain Campus, located approximately 120 kilometers from Turkeyen Campus.

Given that the researchers are also employed at the University of Guyana Library for a significant number of years, participatory and participants' observations were also used to analyse the data

The study population included senior staff members from the University of Guyana, Turkeyen and Tain Campus Libraries.

\subsection{Data Analysis}

The literature in the broad definition included Senior Staff as Library Professionals given their academic qualifications. Most of the Senior Library professionals who participated in the study indicated that they attained their undergraduate or postgraduate qualifications in various disciplines offered at the University of Guyana while a few would have obtained their Information and Library Studies (ILS) from external Universities.

Interviews were conducted with a total of 14 senior library professionals from both the Turkeyen and Tain campuses while the other two were overseas pursuing studies totalling responses from 16 (88.9\%) senior library professionals. The interview schedule collected data on the age, gender, educational qualifications at the commencement of and those acquired during employment. Other data that were collected using the interviewing schedule were: the year the library professionals were employed at the University, their designation, information pertaining to the professional activities of senior staff members including participation in continuing education programmes (CEP), their publications, and their membership in professional associations.

\subsection{General Characteristics}

The analysis of respondents shows that the age range for the 16 senior professionals who participated was below 39 years $(50 \%$ - 8) while $31.25 \%$ (5) were above but below 50 with the remaining $18.75 \%$ (3) were above age 50 . A majority of the participants $(93.75 \%-15)$ were female with $6.25 \%$ (1) being male.

\subsection{Pursuit of Academic Qualifications}

The study showed that $50 \%$ of the current senior library professionals were recruited at the junior level with the basic entry requirement of Caribbean Examination Certificate (CXC) for appointments at UG Library, while $44 \%$ were employed with degrees in the Social Sciences (3), Natural Sciences (1), and the Humanities and Education (3). Only one (6\%) person started 


\section{Macrothink}

International Journal of Learning and Development

ISSN 2164-4063 2019, Vol. 9, No. 4

working with both a Certificate and Degree in Library and Information Science specialised for public libraries.

Table 1. The Academic Qualifications of Senior Library Professionals at Recruitment

Qualification at time of Recruitment (Junior \& Senior Level) Frequency

Percentage (\%)

$\underline{\text { Junior Level }}$

Caribbean Examination Certificate (CXC)

8

50

$\underline{\text { Senior Level }}$

Degree in the Social Sciences

3

18.75

Degree in the Natural Sciences

1

6.25

Degree in the Humanities and Education

3

18.75

Certificate \& Degree in Library and Information Science

1

6.25

Total

16

100

\subsection{Academic Pursuit of Staff Recruited as Junior Staff}

Those who joined the library at the junior level participated in continuous in-house training every two years for a minimum of eight years with promotion up to three levels, the last of which was the para-professional of Senior Library Assistant I. At this juncture these staff members had the choice to either remaining at this position or wait on the university to make scholarships available, or pursue their own thrust for development. All of them opted to pursue available options and pursued basic subject degrees and Graduate studies. 


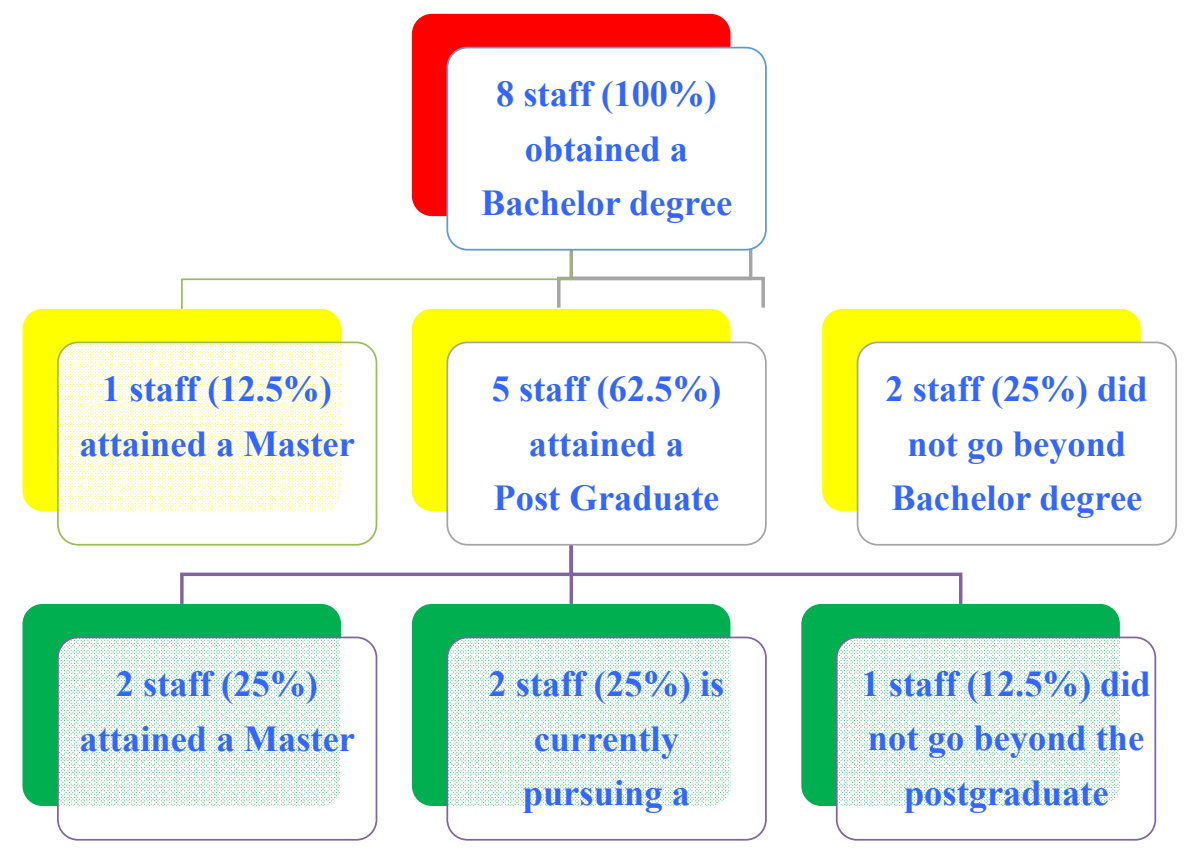

Figure 1. The Academic Pursuit of Senior Library Staff Recruited as a Junior Staff

The three library professionals who did not pursue further studies beyond the degree and post-graduate diploma levels indicated that they experienced financial challenges. They noted that the lack of scholarships which were sparse also came with limitations such as age, family commitments as well lack of interest. They all competed with other applicants for promotion in the library subject to availability of vacancies.

\subsection{Academic Pursuit of Senior Library Professionals Recruited with First Degrees}

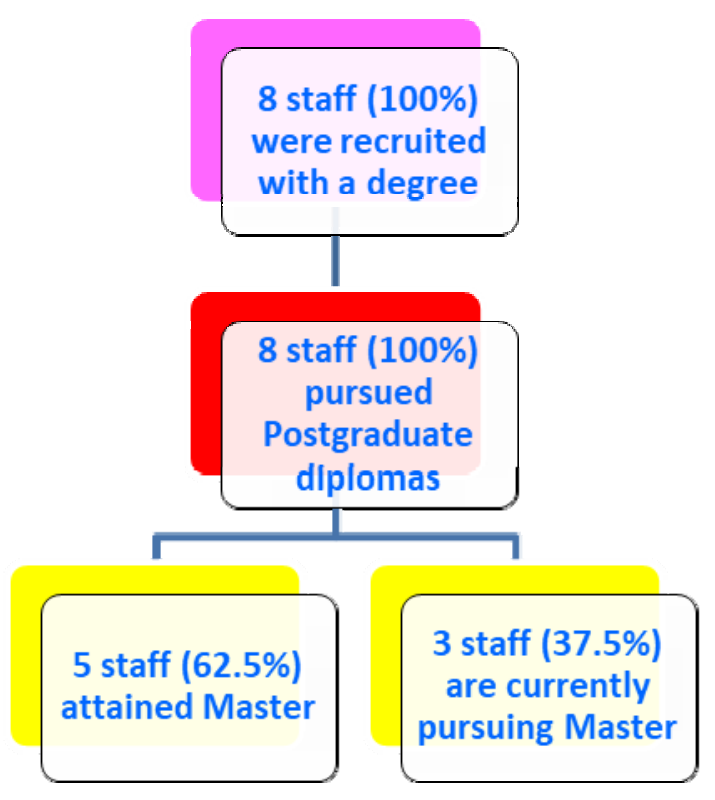

Figure 2. The Academic Pursuit of Senior Library Professionals Recruited with a First Degree 


\section{Macrothink}

International Journal of Learning and Development

ISSN 2164-4063 2019, Vol. 9, No. 4

The other seniors who were recruited with degrees also opted to further their studies as shown in Figure 2 above.

6.6 Current Status of all Senior Staff Academic Qualification

Table 2. Qualification of All Respondents

\begin{tabular}{lll}
\hline Qualification & Frequency & Percentage \\
\hline Master in Library and Information Study & 2 & 12.5 \\
Master in other subject disciplines & 6 & 37.5 \\
Grad. Dip in other subject disciplines & 6 & 37.5 \\
Only at the Bachelor Degree in other subject disciplines & 2 & 12.5 \\
TOTAL & 16 & 100 \\
\hline
\end{tabular}

A total picture in terms of qualifications attained across the 16 senior staff at the University of Guyana Library is illustrated in Table 2.

\section{Participating in Continuing Education Programmes}

Similar to Gelfand (1985), senior library professionals at UG Library pursued alternative avenues to achieve professional and personal development. Most of these activities while partially funded by donor organisations, were explored external to the university's administration. For example, senior library professionals:

i) attended conferences and seminars and presented research papers in the area of their other subject disciplines;

ii) engaged in partially funded and non-funded research work in the field of library and information sciences to keep abreast with changing trends. Debriefing sessions were held with other library professionals to share the research findings;

iii) made presentations to the University community at the Library's Annual Research Day;

iv) presented research papers at National and International forums - ACURIL, IFLA, with or without financial support

v) published papers in conference proceedings, journals, and books

vi) engaged in reading professional literature which serves to keep them abreast with new and emerging library trends; 
vii) engaged in group discussions on various library- related issues;

viii) pursued online courses, participate in Webinars;

ix) became members of Library-related online forums such as ALA and LinkedIn.

\section{Benefits Derived From Increase Continuous Developments}

Senior library professionals at the UG Library identified the following as benefits derived from pursuing professional and personal development:

- Professional and personal growth which helped to update knowledge or basic education, training in the latest technologies and improve relations with fellow library professional;

- Upward mobility - promotion and increase remuneration. As stated earlier in the research, those seniors who were recruited at the junior levels and acquired degree were promoted, received increased remunerations on the completion of their programme. This was accomplished after competing with other library professionals for the position;

- Enhanced knowledge in the field which helped them to be up-to-date with the new and emerging areas and trends in library and information science. For example, one Senior library professionals who attended an overseas course on Digital Services were able to apply knowledge gained to accelerate the implementation of the Library's Online database;

- The ability to apply knowledge acquired in everyday work, boosted the scope for training junior library professionals and aided in the provision of support to the students and faculty of the university.

- From the knowledge, expertise and skills acquired while attending various training programmes, Senior library professionals hosted mini training programmes and acted as facilitators. The junior library professionals benefited from these sessions and on completion were promoted. In addition, arising from the junior professionals' increased knowledge and skills, the quality of services delivery at access points in the library were enhanced;

- Expertise in research and presentations at professional bodies which serves to enhance capacity and provide an avenue for critical assessment of individual research work by other Librarians, varied knowledge on new services offered in libraries and the ability to engage in critical thinking. For example. Senior staff who attended conferences both local and international (ACURIL, IFLA Conferences, UG Library Research Day) benefited from constructive criticism which strengthened their abilities for preparation and presentations of research papers in the future. In addition, constructive criticisms and peer reviews on research papers presented resulted senior Library professionals being able to become equipped with the necessary capacity to publish their articles in academic journals.

\section{Conclusion}

This study indicated that continuous learning, professional and social development tend to lead to transformation of the individual in terms of their academic and social abilities resulting in an 
enhancement of their skills set and competencies, while some responsibilities to achieving this rest with the employer, self-determination, and persistence bring greater rewards.

\subsection{Steps taken by UG Library Professionals for Professional Development and Personal Growth}

\subsubsection{Academic Qualification}

The study provided evidence to support instances where the senior library professionals at the University of Guyana Library did not accept passively the limited opportunities the University administration had to offer. Although the opportunities for pursuit in professional qualifications in the field of Library and Information Science were limited, professional staff members used their initiative and pursued programmes in higher education in other subject disciplines as was shown in Figures 1 and 2.

\subsubsection{Other Steps taken by UG Library staff members}

In addition, senior professionals of UG Library pursued the following avenues to achieve professional development and personal growth, mostly without financial support:

$>$ Participated in conferences and seminars (various subject disciplines);

$>$ Engaged in research work in the field of library and information sciences to keep abreast with changing trends;

$>$ Made presentations at seminars workshops locally, as well as at International forums ACURIL, IFLA;

$>$ Participated in professional networks /interest groups (personal and virtual);

> Joined professional Library related online forums such as ALA, CILIP, LinkedIn;

$>$ Wrote papers for publication in conference proceedings, journals and books;

$>$ Engaged in reading professional literature which serves to keep them current with new and emerging trends;

$>$ Engaged in group discussions on various subject matters;

$>$ Pursued online courses, participate in Webinars in the field of library and information studies which enabled them to apply knowledge acquired to their work benefiting their subordinates and ultimately the students;

As Munde (2000), puts it, Library schools may not graduate enough librarians with the required skill set to fill positions; hence the alternative is to rely on persons with other academic qualifications. And still attain the desired results with them adequately functioning in their role as librarians, participating at conferences with other qualified Librarians, making presentations and engaging in forum discussions on the same level of understanding. UG Library senior professionals have strived to function with their academic qualifications in the capacities of librarians and have managed to excel in services offered to their clientele. 


\section{Macrothink}

International Journal of Learning and Development

ISSN 2164-4063 2019, Vol. 9, No. 4

While the challenges of limited or no access to scholarships due to the lack of or no funding to pursue degrees in Library and Information Studies, may seem insurmountable the need to use their initiatives required some originality, creativity and a selflessness that is a typical attitude in this era. The lack of these will affect competencies on the job, and which will eventually affect the face value of the organisation.

\section{Acknowledgement}

The researchers would like to extend gratitude to the following persons who help make this research a success:

- Special thanks to Dr. Henry Hinds for the professional guidance and expertise provided as well as in editing of the research.

- Thanks to the Library professionals who willingly participated in the interviews.

- Thanks to Rachel Peters for her input for assisting with the formatting of the research paper.

\section{References}

American Library Association. (n.d). Do I need a Library Science Master's Degree? Retrieved from http://www.ala.org/educationcareers/careers/librarycareerssite/whatyouneedmaster

Andrén, U. (2012). Self-awareness and self-knowledge in professions something we are or a skill we learn. Retrieved from https://gupea.ub.gu.se/bitstream/2077/30157/1/gupea_2077_30157_1.pdf.

Bratton, J., \& Gold, J. (2007). Human resource management: Theory and practice. Hampshire: Palgrave Macmillian.

Corwin, B. (2011, November 30). The pros and cons of taking professional development programs online [Blog post]. Retrieved from http://learnmore.uncg.edu/blog/bid/107337/The-pros-and-cons-of-taking-professional-develo pment-programs-online

Courtenay, S. (1989). Defining adult and continuing education. In S.B. Merriam \& P.M. Cunningham (Eds.), Handbook of adult and continuing education (pp.26-36). San Francisco: Jossey-Bass.

Drucker, P. F. (1992). Managing for the future. Oxford: Butterworth-Heinemann.

Emory University College of Arts and Applied Science. (n.d.). Staff professional development. Retrieved from http://college.emory.edu/home/administration/employment/development.html

Gelfand, J. (1985). Professional development for reference and adult services librarians. $R Q$, $24,402-410$.

Gilley, J. W., \& Maycunich, A. (2000). Organizational learning, performance and change: An introduction to strategic human resource development. Cambridge, MA: Perseus. 
Gremmels, G. S. (2013). Staffing trends in college and university libraries. Reference Services Review, 41(2), 233 - 252. https://doi.org/10.1108/00907321311326165

Guskey, T. (2003). What makes professional development effective? Phi Delta Kappan, 84(10), 748-750. https://doi.org/10.1177/003172170308401007

Hare, A. (1989). Professional development in the 1980s in college libraries in the South-East. Southeastern Librarian, 39, 18-19.

Havener, W. M., \& Stolt, W. (1994). The professional development activities of academic librarians: Does institutional support make a difference? College \& Research Libraries, 55(1), 25-36. https://doi.org/10.5860/crl_55_01_25

Jain, P., \& Mutula, S. (2008). Libraries as learning organisations: Implications for knowledge management. Library Hi Tech News, $25(8), \quad$ 10-14. https://doi.org/10.1108/07419050810931273

James, F., Phillip, S., Herbert, S. Augustin, D. S., Yamin-Ali, J., Ali, S., \& Rampersad, J. (2013). Is anybody listening? Teachers' views of their in-service teacher professional development programme. Caribbean Curriculum, 20, 77-100.

Kar, A. K. (2011). Importance of life skills for the professionals of 21 st Century. The IUP Journal of Soft Skills, 3(5), 35-45.

Larsen, G. (2007, August 19-23). Preparing library staff for reference and information work in the hybrid library - the need for skills and continuing professional development. Paper presented at the Annual IFLA Conference, Durban, South Africa. Retrieved from https://archive.ifla.org/IV/ifla73/papers/151-Larsen-en.pdf

Knight, J. (2015). Investing in human resource development: Strategic planning for success in academic libraries. Advances in Library Administration and Organization 33, 1-42. https://doi.org/10.1108/S0732-067120150000033001

Lowe, D., \& La Rose, S. (2015). Aspiring for higher achievements, the determination to finding pathways to professional and personal development: The reality at the University of Guyana. Paper presented at the 45th ACURIL Conference, Paramaribo, Suriname.

McCreadie, N. (2013). Library value in the developing world. International Federation of $\begin{array}{llll}\text { Library Associations } \quad \text { and 327-343. } & \text { 3nstitutions, }\end{array}$ https://doi.org/10.1177/0266666913510114

Mizell, H. (2010). Why professional development matters? Retrieved from http://learningforward.org/docs/pdf/why_pd_matters_web.pdf

Munde, G. (2000). Beyond mentoring: Toward the rejuvenation of academic libraries. Journal of Academic Librarianship, (20), 171-175. https://doi.org/10.1016/S0099-1333(00)00095-1

National Institute of Health, USA. (n.d.). Continuous learning and self-development. Retrieved from http:/Hr.ord.nih.gov/workingatnih/competencies/core/continiouslearn.htm Continuous learning and self-development 


\section{Macrothink}

International Journal of Learning and Development

ISSN 2164-4063 2019, Vol. 9, No. 4

Pan, J., \& Hovde, K. (2010). Professional development for academic librarians: Needs, resources, and administrative support. Chinese Librarianship: An International Electronic Journal, 29, 1-9. Retrieved from http://www.iclc.us/cliej/cl29PH.pdf

Porter, M. E., \& Kramer, M. R. (2011). Creating shared value. Harvard Business Review, $89(1-2), 62-77$.

Simpson, B. (2013). Hiring non-MLS Librarians: Trends and training implications. Library Leadership and Management, 28(1), 1-15.

University of Guyana Personnel Division. (2011). Handbook for guidance of UB and supervisory staff. Georgetown, Guyana: University Personnel Division.

Varlejs, J. (2010). Continuing professional development: Principles and best practices. Paper presented at the IFLA Conference, Gothenburg, Sweden. Retrieved from https://www.ifla.org/files/assets/cpdwl/guidelines/cpdwl-qual-guide.pdf

Verzosa, F. A. M. (2009). Best practices: A professional development for librarians. Paper presented at the MAHLAP Congress, Tagaytay City. Retrieved from http://www.slideshare.net/verzosaf/best-practices-professional-development-for-librarians

\section{Copyright Disclaimer}

Copyright for this article is retained by the author(s), with first publication rights granted to the journal.

This is an open-access article distributed under the terms and conditions of the Creative Commons Attribution license (http://creativecommons.org/licenses/by/4.0/). 